\title{
UJI KETAHANAN KLON KARET IRR SERI 400 TERHADAP BEBERAPA ISOLAT PENYAKIT GUGUR DAUN Colletotrichum
}

\author{
Resistance Test of Rubber IRR 400 Series to Saveral Isolates \\ Colletotrichum Leaf Fall Disease \\ Syarifah Aini PASARIBU ${ }^{1)}$, ROSMAYATI ${ }^{2)}$, dan SUMARMADJI ${ }^{1)}$ \\ 1) Balai Penelitian Sungei Putih, Pusat Penelitian Karet \\ P.O. Box 1415 Medan 20001 Sumatera Utara \\ Email: balitsp@indosat.net.id \\ ${ }^{2)}$ Fakultas Pertanian, Universitas Sumatera Utara \\ Jln. dr.T.Mansur No.9 Kampus USU Medan 20155 \\ Email: tanjungrosmayati@yahoo.co.id
}

Diterima : 10 Juli 2015 / Direvisi : 8 September 2015 / Disetujui : 25 September 2015

\begin{abstract}
Creating clones with high productivity, vigour, resistant to leaf fall disease and wide adaptability is breeding rubber purpose. Clones IRR 400 series are candidate for the next IRR series has a greater potential yield than PB 260. Especially for disease resistance, creating resistant clones carried out by crossing between parent who have high yield potential and disease resistance. Colletotrichum leaffall disease is one of the most important diseases. Disease caused by fungus of Colletotrichum gloeosporioides. This disease can decrease productivity, delay for grafting in the nursery, and in severe attacks make seed defective, dwarf and die. Therefore, the research was conducted at Sungei Putih Research Centre, in scion garden to find the resistance of 22 clones IRR 400 series and clone controlPB 260. Parameters to be observed were attacks intensity and laten period. Then to see the resilience of genetically tested heretability $\left(h^{2}\right)$ with compare genetic diversity with environments diversity. There were six clones had a high level to attack intensity of Colletotrichum resistance viz IRR 428, IRR 429, IRR 446, IRR 451 and IRR 452. There was no interaction between isolates with clones selected because isolate used was Colletotrichum gloeosporioides. Resistance level affected by clones was reflected from high heretability $>0.5$.
\end{abstract}

Keywords: IRR 400 series, Colletotrichum, heretability

\section{Abstrak}

Perakitan klon dengan produktivitas tinggi, pertumbuhan jagur, resisten terhadap penyakit gugur daun serta memiliki daya adaptabilitas luas adalah tujuan pemuliaan karet. Klon IRR seri 400 merupakan calon klon unggul seri IRR berikutnya yang memiliki potensi produksi melebihi klon PB 260. Khusus untuk ketahanan penyakit, pendekatan dengan perakitan klon tahan juga telah dilakukan, yaitu menyilangkan tetua yang memiliki potensi produksi tinggi dan tahan penyakit. Penyakit gugur daun Colletotrichum merupakan salah satu penyakit terpenting pada tanaman karet.Penyakit ini disebabkan oleh cendawan Colletotrichum gloeosporioides. Gangguan penyakit ini dapat menurunkan produktivitas kebun, tertundanya saat okulasi di pembibitan, dan dalam serangan yang berat mengakibatkan bibit cacat, kerdil bahkan mati. Oleh karena telah dilakukan penelitian di Balai Penelitian Sungei Putih di kebun Entres untuk mengetahui ketahanan 22 klon IRR seri 400 dan klon pembanding PB 260. Parameter yang diamati adalah intensitas serangan dan periode laten, kemudian untuk melihat sifat ketahanan, dicari nilai heretabilitas $\left(\mathrm{h}^{2}\right)$ dengan membandingakan ragam genetik dan ragam lingkungan terhadap parameter pengamatan. Terseleksi enam klon yang memiliki tingkat ketahanan yang tinggi terhadap intensitas serangan Colletotrichum yaitu IRR 428, IRR 429, IRR 446, IRR 451 dan IRR 452. Tidak adanya interaksi antara isolat dengan klon karena jenis isolat yang digunakan adalah Colletotrichum gloeosporioides. Tingkat ketahanan dipengaruhi oleh klon yang dicerminkan dari nilai heretabilitas tinggi yaitu $>0,5$.

Kata kunci: IRR seri 400, Colletotrichum, heretabilitas 


\section{PENDAHULUAN}

Salah satu komoditas perkebunan Indonesia yang merupakan sumber devisa negara adalah karet. Oleh karena itu sasaran penelitian tanaman karet diarahkan untuk mendapatkan klon unggul baru yang memiliki potensi produktivitas tinggi. Klon karet unggul komersial saat ini telah memiliki potensi produktivitas 2500-3000 $\mathrm{kg} / \mathrm{ha} / \mathrm{thn}$ (Aidi Daslin et al., 2009). Potensi produktivitas tersebut masih dapat ditingkatkan sampai $7000 \mathrm{~kg} / \mathrm{ha} /$ thn (Aziz, 1998), sehingga membuka peluang ditemukannya klon-klon unggul baru yang memiliki potensi produksi lebih dari 3000 $\mathrm{kg} / \mathrm{ha} /$ thn.

Program pemuliaan tanaman karet bertujuan untuk merakit klon dengan produktivitas tinggi, pertumbuhan jagur, resisten terhadap penyakit gugur daun serta memiliki daya adaptabilitas yang luas. Pada daerah kering, pertumbuhan tanaman terhambat dan produktivitasnya lebih rendah. Sementara pada daerah basah, tanaman mempunyai resiko lebih besar terserang penyakit daun dan penyakit bidang sadap (Hadi, 2003).

Penyakit gugur daun Colletotrichum merupakan salah satu penyakit penting pada tanaman karet dan dapat menjadi ancaman bagi kelangsungan budidaya karet di Indonesia. Penyakit ini disebabkan oleh cendawan Colletotrichum gloeosporioides. Penurunan produksi yang ditimbulkan akibat penyakit ini bervariasi antara $7-45 \%$, tergantung dari intensitas serangan (Pawirosoemardjo dan Suryaningtyas, 2008). Selain itu, serangan di areal pembibitan mengakibatkan tertundanya saat okulasi dan dalam serangan yang berat mengakibatkan bibit cacat, kerdil bahkan mati. Pada tanaman produksi di lapangan, serangan dapat mengakibatkan gugurnya daun-daun muda, sehingga tajuk tanaman tipis dan perkembangan lilit batang terhambat serta tertundanya matang sadap (Basuki et al. 1990). Epidemi tersebut timbul karena terjadinya penyimpangan pola iklim, yaitu kemarau panjang yang diikuti oleh hujan sepanjang tahun, kondisi tanaman lemah karena kurang pemeliharaan, serta penanaman klon rentan (Pawirosoemardjo, 2004).
Epidemi penyakit yang menimbulkan kerusakan sangat parah dilaporkan terjadi di Jawa yang menyerang klon GT1 pada tahun 1973 sampai 1975 dan di Sumatera tahun 1976 (Soepadmo, 1975). Selanjutnya pada tahun 1989 terjadi epidemi yang sangat berat di Kalimantan Barat dengan luas kerusakan mencapai 24.000 ha (Soepena, 1995).Serangan penyakit merebak pada tanaman karet rakyat secara berkepanjangan sampai tahun 1992. Banyak tanaman yang mengalami mati pucuk bahkan banyak pula pohon-pohon mati.

Bekas serangan penyakit terlihat pada tanaman tua, sampai tahun 1993 masih banyak tanaman yang meranggas dengan dahan dan rantingnya mati (Soepena, 1995).

Fenomena gugur daun juga terjadi di beberapa kebun PTP VIII, yaitu kebun Cibungur, Jalupang, Batu Lawang dan Cikupa. Gugur daun terjadi sepanjang tahun 2010 sampai pertengahan 2011, akibatnya daun muda yang terbentuk gugur kembali. Tajuk tanaman sangat tipis perdaunannya (25\%-30\%) akibat terserang penyakit gugur daun Colletotrichum dan Oidium, sehingga menyebabkan produksi menurun $25 \%$. Klon yang terserang adalah LCB 1320, RRIM 600, RRIM 712, RRIM 703 dan PR 255 (Balai Penelitian Sungei Putih, 2011). Dalimunthe et al., (2014), menyatakan bahwa potensi kerugian akibat penyakit gugur daun di perkebunan karet Sumatera Utara cukup besar. Produksi turun sebesar 30\%, maka potensi kehilangan pendapatan lebih dari 2 triliun rupiah/tahun, dan hal ini meningkat setiap tahunnya. Asumsi tahun 2018 pendapatan akan terus berkurang menjadi lebih 3 triliun rupiah/tahun.

Sejauh ini metode pengendalian yang diterapkan adalah secara kimiawi dengan menggunakan berbagai jenis fungisida. Pengendalian ini membutuhkan biaya mahal dan dapat mengakibatkan pencemaran lingkungan yang tinggi. Penggunaan klon karet unggul yang resisten merupakan salah satu strategi pengendalian yang murah dan ramah lingkungan (Rahayu et al., 2005). 
Usaha yang dapat dilakukan untuk memperoleh klon karet yang tahan terhadap penyakit adalah dengan menyilangkan tetua karet yang tahan penyakit, sehingga dihasilkan keturunan yang tahan. Tetua persilangan yang mempunyai sifat ketahanan cukup baik sebagian besar berasal dari klon-klon sekunder dan tersier seperti BPM 1, BPM 24, RRIC 100, serta klon introduksi seperti F 4542, FX 25, FX 2784, dan FX 4037. Mulai tahun 1995 beberapa genotipe terpilih material IRRDB 1981 (PN 6, PN 7, PN 1505 dan PN 2662) yang memiliki pertumbuhan jagur dan tergolong tahan penyakit daun telah dimasukkan dalam program pemuliaan untuk perbaikan karakteristik sekunder (Aidi-Daslin et al., 2009).

Klon IRR seri 400 merupakan klon hasil seleksi Balai Penelitian Sungei Putih, Pusat Penelitian Karet. Material genetik yang diseleksi merupakan hasil persilangan tahun 1996/1997 yang menghasilkan 101 progeni (tanaman F1). Progeni yang terseleksi berdasarkan sifat pertumbuhan dan produksi tersebut kemudian disebut sebagai klon IRR seri 400. Saat ini klon IRR seri 400 tersebut sudah ditanam di areal pengujian pendahuluan yang dibangun sejak tahun 2004. Dari hasil pengamatan produksi, terseleksi beberapa klon yang memiliki potensi hasil lebih dari $50 \mathrm{~g} / \mathrm{p} / \mathrm{s}$.

Seleksi ketahanan klon karet terhadap penyakit gugur daun dapat diketahui dengan menggunakan metode konvensional dan molekuler (Darmono et al., 1996; Silva et al., 1998; Saha et al., 2000). Pendekatan secara konvensional dilakukan dengan mengamati beberapa parameter genetik yang tercermin dengan menghitung tingkat keparahan penyakit dan periode laten. Parameter tersebut juga digunakan untuk mengetahui pola pewarisan suatu klon terhadap ketahanan penyakit gugur daun. Hal tersebut dapat dilakukan jika keragaman populasi luas (Syukur et al., 2012). Mudah tidaknya pewarisan suatu karakter dapat diketahui dari besarnya nilai heretabilitas $\left(\mathrm{h}^{2}\right)$ yang dapat diduga dengan membandingkan besarnya ragam genotipe terhadap ragam fenotipe (Borojevic, 1990; Syukur et al., 2012).

\section{BAHAN DAN METODE}

Penelitian ini dilaksanakan di Kebun Entres Balai Penelitian Sungei Putih dengan uji ketahanan diferensial terhadap daun dari 22 klon IRR seri 400 (HP 1996/1997) dan klon pembanding PB 260 terhadap tiga isolat Colletotrichum. Tiga isolat Colletotrichum yang digunakan berasal dari Sungei Putih, Sembawa dan Getas. Penelitian ini menggunakan Rancangan Petak Tersarang (Nested Design). Faktor perlakuan terdiri atas dua, yaitu klon dan isolat dan menggunakan tiga ulangan. Model linier yang digunakan adalah :

Yijk $=\mu+\mathrm{Ti}+\beta \mathrm{j}+\gamma \mathrm{k} / \mathrm{i}+(\mathrm{T} \beta) \mathrm{ij}+\varepsilon(\mathrm{ij}) \mathrm{k}$, dimana :

Yijk : Respon yang ditimbulkan pada unit percobaan yang mendapat perlakuan klon dan isolat kombinasi ke-ij dengan ulangan ke$\mathrm{k}$.

$\mu \quad$ : Pengaruh rataan percobaan.

Ti : Pengaruh jenis klon sebanyak i taraf.

Bj $\quad$ : Pengaruh jenis isolat Colletotrichum sebanyak j taraf.

$\gamma \mathrm{k} / \mathrm{i}$ : Pengaruh ulangan ke $\mathrm{k}$ yang tersarang pada klon sebanyak i taraf.

(Tß)ij : Pengaruh interaksi yang ditimbulkan oleh perlakuan klon dan isolat ke-ij.

$\varepsilon(i j) \mathrm{k} \quad$ : Pengaruh galat yang bekerja pada unit percobaan yang mendapat perlakuan klon dan isolat kombinasi ke-ij dengan ulangan ke-k.

Bila dalam pengujian sidik ragam diperoleh pengaruh perlakuan yang nyata atau sangat nyata, maka uji beda antar perlakuan dilakukan uji jarak Duncan Multiple Range Test (DNMRT) (Montogomery, 2001).

Bahan tanam di kebun entres dipangkas \pm 2 bulan sebelum pelaksanaan inokulasi jamur untuk memperoleh pertumbuhan tanaman yang seragam. Jika pada saat aplikasi tanaman tidak seluruhnya tumbuh secara seragam maka 
aplikasi dapat dilakukan pada tanaman yang memenuhi syarat untuk diaplikasi. Larutan konidia Colletotrichum dengan konsentrasi $4 \times 10^{4} \mathrm{spora} / \mathrm{ml}$ disemprotkan ke permukaan bawah daun tengah yang berwarna kecokelat-cokelatan. Satu klon terdiri dari tiga pohon, dan dari satu pohon diambil tiga cabang, masing-masing untuk isolat yang berbeda. Setelah disemprot daun disungkup dengan plastik transparan. Inkubasi berlangsung selama 2 hari. Setelah dua hari plastik pembungkus dibuka dengan tetap memberi label setiap tangkai perlakuan. Pengamatan keparahan penyakit dilakukan pada hari ke-7, 14 dan 21 hari setelah inokulasi spora.

Parameter yang diamati dalam penelitian ini adalah tingkat keparahan penyakit (intensitas serangan), periode laten, tebal kutikula, dan jumlah stomata.

Pengamatan intensitas penyakit adalah sebagai berikut:

\section{A. Intensitas Serangan Penyakit Skala bercak daun}

Pengukuran skala bercak daun karet terserang Colletotrichum di lapangan dilakukan menurut metode Pawirosoemardjo (1984) yang telah dimodifikasi. Skala bercak daun ditetapkan menjadi tujuh taraf, yaitu:

Skala 0 = tidak terdapat bercak pada daun

Skala 1 = terdapat 1 sampai 8 bercak pada daun

Skala 2 = terdapat 9 sampai 12 bercak pada daun

Skala 3 = terdapat 13 sampai 16 bercak pada daun

Skala 4 = terdapat 17 sampai 20 bercak pada daun
Skala $5=$ terdapat 21 sampai 24 bercak pada daun

Skala 6 = terdapat lebih dari 24 bercak pada seluruh permukaan daun

\section{Skala Cacat Daun}

Skala 0 = tidak terdapat daun yang cacat

Skala $1=$ terdapat $1 / 16$ bagian daun yang cacat

Skala 2 = terdapat $1 / 8$ bagian daun yang cacat

Skala 3 = terdapat $1 / 4$ bagian daun yang cacat

Skala 4 = terdapat $1 / 2$ bagian daun yang cacat

Skala 5 terdapat lebih dari $1 / 2$ bagian daun yang cacat

Skala 6 = terdapat seluruh daun yang cacat atau daunnya gugur

Tingkat keparahan penyakit dihitung dengan menggunakan rumus sebagai berikut:

$$
\text { IS }=\frac{\sum\left(\mathrm{n}_{\mathrm{i}} \times \mathrm{v}_{\mathrm{i}}\right)}{\mathrm{N} \times \mathrm{Z}} \times 100 \%
$$

Keterangan;

IS : Intensitas serangan

$\mathrm{n}_{\mathrm{i}} \quad$ : Jumlah daun ke $\mathrm{i}$ pada skala serangan (v) ke I

$\mathrm{v}_{\mathrm{i}} \quad$ : Skala dari tiap kategori serangan

$\mathrm{N}$ : Jumlah seluruh daun yang diamati

Z : Skala serangan tertinggi

(Pawirosoemardjo, 1984)

Klasifikasi penilaian intensitas serangan (IS) penyakit Colletotrichum adalah:

$\begin{array}{ll}\text { Resisten } & : 0-20 \% \\ \text { Agak Resisten } & : 21-40 \% \\ \text { Moderat } & : 41-60 \% \\ \text { Agak Peka } & : 61-80 \% \\ \text { Peka } & : 81-100 \%\end{array}$

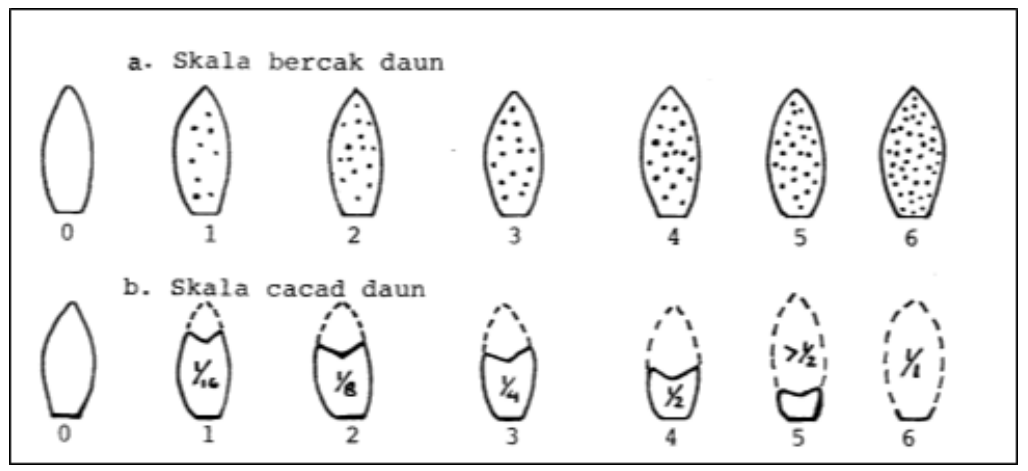

Gambar 1. Metode penentuan skala bercak dan cacat daun

Figure 1. Method of determining spot scale and deefective leaf 


\section{A. Periode Laten}

Periode laten merupakan interval dimulai dari inokulasi sampai sporulasi pertama kali terdeteksi. Pengamatan dilakukan secara umum terhadap daun semua klon yang di uji, apabila terlihat ada satu sampel daun yang terinfeksi maka hal tersebut sudah dicatat sebagai periode laten klon tersebut.
Analisis ragam uji resistensi tanaman karet terhadap penyakit gugur daun Colletotrichum dilakukan dengan menggunakan model Singh dan Chaudhary (1979) dalam Woelan et al. (2009) yang tertera pada Tabel 1.

Berdasarkan sidik ragam pada Tabel 1 , dapat dihitung nilai ragam genotipe $\left(\delta^{2}\right)$ dan ragam fenotipe $\left(\delta_{p}^{2}\right)$ yaitu sebagai berikut:.

Tabel 1. Model analisis ragam uji resistensi klon IRR seri 400 terhadap penyakit gugur daun Colletotrichum.

Table 1. Analysis of variance of IRR 400 series to test resistance of Colletotrichum leaffall disease

\begin{tabular}{cccc}
\hline $\begin{array}{c}\text { Sumber } \\
\text { keragaman }\end{array}$ & $\begin{array}{c}\text { Derajat bebas } \\
\text { Degree of } \\
\text { freedom }\end{array}$ & $\begin{array}{c}\text { Kuadrat } \\
\text { tengah } \\
\text { Mean square }\end{array}$ & $\begin{array}{c}\text { Kuadrat tengah } \\
\text { harapan } \\
\text { Expected mean square }\end{array}$ \\
\hline Klon (A) & $\mathrm{a}-1$ & $\mathrm{M} 1$ & $\delta^{2} e+r b \delta^{2} a$ \\
Isolat (B) & $\mathrm{b}-1$ & $\mathrm{M} 2$ & $\delta^{2} e+r a \delta^{2} b$ \\
AB & $(\mathrm{a}-1)(\mathrm{b}-1)$ & $\mathrm{M} 3$ & $\delta^{2} e+r \delta^{2} a b$ \\
Galat & $(\mathrm{ab}-1)(\mathrm{r}-1)$ & $\mathrm{M} 4$ & $\delta^{2} e$ \\
Total & $\mathrm{abr}-1$ & & \\
\hline
\end{tabular}

Ragam Genotipe $\left(\delta_{\mathrm{g}}^{2}\right)=\frac{\mathrm{M} 1-\mathrm{M} 4}{\mathrm{rb}}$

Ragam Lingkungan $\left(\delta^{2}\right)=\quad$ M4

Ragam Fenotipe $\left(\delta_{\mathrm{p}}^{2}\right)=\delta_{\mathrm{g}}^{2}+\delta_{\mathrm{e}}^{2}$

Nilai heritabilitas dalam arti luas $\left(\mathrm{h}^{2}\right)$ dihitung berdasarkan rumus yang dikemukakan Allard (1960) dalam Syukur et al. (2012) sebagai berikut:

$h^{2}=\left(\delta^{2} g\right) /\left(\delta^{2 p}\right)$

Notasi X adalah skor rata-rata hasil pengamatan secara visual terhadap klon karet yang diuji. Kriteria heritabilitas dalam arti luas menggunakan acuan Allard (1960) dalam Syukur et al. (2012), nilai heritabilitas tinggi apabila $h^{2}>0,50$, dan tergolong sedang apabila $\mathrm{h}^{2}=0,20-0,50$ serta rendah apabila $h^{2}<0,20$.

\section{HASIL DAN PEMBAHASAN}

Hasil analisis sidik ragam terhadap sifat ketahanan klon IRR Seri 400 dengan klon pembanding PB 260 terhadap tiga isolat penyakit gugur daun Colletotrichum yang dilakukan memperlihatkan pengaruh nyata klon, baik pada pengamatan hari ke-7, 14, maupun hari ke-21 setelah inokulasi. Hasil pengamatan tersebut dapat dilihat pada Tabel 2.

Tabel 2 memperlihatkan bahwa intensitas serangan yang terjadi pada klon yang diuji bervariasi antara 8,02-50,62\%. Dengan demikian tingkat ketahanan klon yang diuji tergolong ke dalam moderat sampai resisten.Namun demikian, bila dibandingkan dengan klon PB 260 (9,88\%) terlihat bahwa pada pengamatan $7 \mathrm{hsi}$ hanya klon IRR 451 yang memiliki sifat ketahanan yang lebih tinggi walaupun 
Tabel 2. Resistensi klon IRR seri 400 terhadap penyakit gugur daun Colletotrichum Table 2. Resistance of clone IRR 400 series to Colletotrichum leaffall disease

\begin{tabular}{|c|c|c|c|c|}
\hline \multirow[t]{2}{*}{$\begin{array}{l}\text { Klon }(\mathrm{K}) \\
\text { Clones }\end{array}$} & \multicolumn{3}{|c|}{$\begin{array}{c}\text { Attack intensity } \\
(\%)\end{array}$} & \multirow[t]{2}{*}{$\begin{array}{l}\text { Resistensi klon } 21 \mathrm{hsi} \\
\text { Clone resistance of } 21 \text { dai }\end{array}$} \\
\hline & 7 hsi & 14 hsi & $21 \mathrm{hsi}$ & \\
\hline IRR 425 & 16,7 hi & 18,5 efg & $21,6^{\text {fgh }}$ & Agak resisten \\
\hline IRR 428 & $12,4^{\mathrm{k}}$ & $15,4 \mathrm{~h}$ & $16,7 \mathrm{ij}$ & Resisten \\
\hline IRR 429 & $14,8 \mathrm{ij}$ & $15,4 \mathrm{~h}$ & $16,1^{\mathrm{ij}}$ & Resisten \\
\hline IRR 431 & $37,7^{\mathrm{ab}}$ & $37,7^{\mathrm{c}}$ & $43,8 \mathrm{bc}$ & Moderat \\
\hline IRR 434 & $19,1 \mathrm{fg}$ & 20,9 e & 20,9 ghi & Agak resisten \\
\hline IRR 437 & $13,6 \mathrm{jk}$ & 19,1 ef & 19,1 hij & Agak resisten \\
\hline IRR 440 & 15,4 hij & $16,7^{\text {fgh }}$ & 16,7 ij & Resisten \\
\hline IRR 443 & 38,9 a & 50,6 a & 50,6 a & Moderat \\
\hline IRR 444 & $17,3 \mathrm{gh}$ & $28,4 \mathrm{~d}$ & 28,4 ghi & Agak resisten \\
\hline IRR 445 & $19,8^{f}$ & $25,9 \mathrm{~d}$ & 25,9 ef & Agak resisten \\
\hline IRR 446 & $14,2 \mathrm{jk}$ & 16,7 fgh & $16,7 \mathrm{ij}$ & Resisten \\
\hline IRR 447 & 28,4 c & $42,6^{b}$ & $45,7^{b}$ & Moderat \\
\hline IRR 448 & $20,4^{\mathrm{ef}}$ & $27,2^{\mathrm{d}}$ & $27,2^{\mathrm{e}}$ & Agak resisten \\
\hline IRR 449 & 16,7 hi & 17,9 fgh & 17,9 hij & Resisten \\
\hline IRR 450 & $14,8 \mathrm{ij}$ & $15,4 \mathrm{~h}$ & $16,7 \mathrm{ij}$ & Resisten \\
\hline IRR 451 & $8,0^{1}$ & $14,8^{h}$ & $15,4 j$ & Resisten \\
\hline IRR 452 & 16,7 hi & 17,9 fgh & 17,9hij & Resisten \\
\hline IRR 453 & $12,9 \mathrm{jk}$ & 20,9 e & $21,6 \mathrm{fgh}$ & Agak resisten \\
\hline IRR 454 & 20,9 ef & $25,3 \mathrm{~d}$ & $25,3 \mathrm{efg}$ & Agak resisten \\
\hline IRR 455 & 20,9 ef & $35,8^{c}$ & $38,9 \mathrm{c}$ & Agak resisten \\
\hline IRR 456 & $21,6^{\mathrm{e}}$ & $26,5^{\mathrm{d}}$ & $40,1^{c}$ & Moderat \\
\hline IRR 457 & $20,9^{d}$ & $35,8^{c}$ & $32,1 \mathrm{~d}$ & Agak resisten \\
\hline PB 260 & $9,9^{1}$ & $16,1^{\mathrm{gh}}$ & $16,1^{\mathrm{ij}}$ & Resisten \\
\hline
\end{tabular}

Keterangan: Angka yang diikuti huruf yang samapada kolom yang sama menunjukkan tidak berbeda nyata pada taraf 5\% menurut uji DMRT (Duncan Multiple Range Test).

Note: The figures followed the same letter in the same column showed no significant difference in the level of 5\% by DMRT (Duncan Multiple Range Test).

secara statistik dianalisis sama yaitu sebesar $8,02 \%$. Pengamatan 14 hsi ada dua klon yang memiliki tingkat resistensi lebih tinggi dibanding klon PB 260 (16,05\%) yaitu klon IRR $450 \quad(15,43 \%)$ dan IRR 451 $(14,81 \%)$. Pengamatan 21 hsi juga ada satu klon yang tingkat resistensinya lebih tinggi dengan klon PB 260 (16,05\%), yaitu klon IRR 451 yaitu sebesar $15,43 \%$.

Ketahanan terhadap suatu penyakit pada berbagai varietas tanaman tidak sama. Ketahanan terhadap suatu penyakit dikendalikan oleh gen-gen ketahanan yang terekspresi sebagai sifat morfologi tanaman yang akan mendukung terjadinya mekanisme ketahanan terhadap penyakit tersebut. Ketahanan dapat terjadi karena kemampuan tanaman untuk membentuk struktur-struktur tertentu yang tidak menguntungkan bagi patogen (Wiratama et al., 2013). Salah satu penyebab gen ketahanan tidak muncul adalah karena gen ketahanan itu dikendalikan oleh beberapa gen minor dan bersifat kuantitatif yang berarti dipengaruhi oleh lingkungan (Yunasfi, 2002).

Perlakuan jenis isolat menunjukkan pengaruh yang tidak nyata terhadap intensitas serangan pada pengamatan ke-7, 14, dan 21 hsi yang diujikan pada klon IRR seri 400 dan klon pembanding PB 260.Hasil pengamatan tersebut dapat dilihat pada Tabel 3. 
Tabel 3. Pengaruh faktor isolat (I) terhadap rataan intensitas serangan Colletotrichum (\%) di kebun entres

Table 3. Isolate influence (I) to mean intensity of Colletotrichum attacking (\%) in scion garden

\begin{tabular}{lccc}
\hline \multirow{2}{*}{$\begin{array}{c}\text { Isolat (I) } \\
\text { Isolate (I) }\end{array}$} & \multicolumn{3}{c}{$\begin{array}{c}\text { Intensitas serangan } \\
\text { Attack intensity } \\
(\%)\end{array}$} \\
\cline { 2 - 4 } & $7 \mathrm{hsi}$ & $14 \mathrm{hsi}$ & $21 \mathrm{hsi}$ \\
\hline Sungei Putih & 17,63 & 18,36 & 20,85 \\
Sembawa & 21,66 & 23,67 & 28,02 \\
Getas & 22,22 & 24,15 & 30,68 \\
\hline
\end{tabular}

Tabel 3 memperlihatkan bahwa perlakuan isolat terhadap intensitas serangan memiliki variasi antara 17,63$30,68 \%$. Pada semua waktu pengamatan $(7$, 14, 21 hsi) menunjukkan bahwa isolat asal Getas memiliki intensitas serangan tertinggi, yaitu sebesar 22,22\%, 24,15\%, dan 30,68\%. Kemudian juga terlihat persamaaan intensitas serangan pada 7 dan $14 \mathrm{hsi}$, dimana intesitas serangan terendah terlihat pada isolat asal Sungei Putih yaitu 17,63\% dan $20,85 \%$.

Pengaruh intensitas serangan dari beberapa isolat secara umum diduga karena kondisi lingkungan. Faktor lingkungan tersebut adalah faktor biotik dan abiotik. Faktor biotik adalah tanaman inang sebagai tempat hidup patogen tersebut dan jasad renik yang ada di sekitar patogen yang menyebabkan patogen dapat bertahan hidup dan mampu bersaing dengan jasad renik lainnya. Tanaman karet merupakan salah satu tanaman inang yang baik dalam melewati seluruh daur hidup jamur Colletotrichum tersebut (Senechal et al., 1987 cit Lopez dan Lucas, 2010). Sementara faktor abiotik diantaranya ketinggian tempat, curah hujan, kelembaban, dan $\mathrm{pH}$ tanah. Faktor abiotik tertentu dapat menyebabkan tanaman mengalami cekaman sehingga penyakit yang ditimbulkan patogen menjadi lebih berat bila tanaman hanya terserang oleh patogen saja. Sa'diyah dan Aeny (2012), menyatakan bahwa perkembangan penyakit tergantung pada kondisi cuaca panas dan kelembaban tinggi.

Interaksi antara perlakuan klon dengan jenis isolat terlihat tidak berpengaruh nyata terhadap intensitas serangan pada pengamatan 7,14 , dan 21 hsi yang diaplikasikan pada klon IRR seri 400 dan klon pembanding PB 260. Hasil pengamatan tersebut dapat dilihat pada Tabel 4.

Tabel 4 memperlihatkan bahwa kombinasi antara klon dan isolat memiliki intensitas serangan antara 12,96-70,37\% yang diamati pada hari ke-7, 14, dan 21 hsi.

Pengamatan 7 hsi menunjukkan bahwa klon pembanding PB 260 asal isolat Sembawa memiliki tingkat ketahanan paling tinggi (3,70\%), namun demikian dari klon IRR seri 400 yang diuji, ada satu klon yang memiliki tingkat ketahanan yang sama dengan klon PB 260 yaitu klon IRR 451 asal isolat Getas (3,70\%).

Pengamatan 14 hsi menunjukkan bahwa klon pembanding PB 260 asal isolat Sembawa dan Getas juga memiliki tingkat ketahanan tertinggi, dengan nilai intensitas serangan 12,96\% untuk isolat asal Sembawa dan $14,81 \%$ untuk isolat asal Getas. Terdapat empat klon seri IRR 400 yang memiliki tingkat ketahanan yang sama dengan klon pembanding PB 260 tersebut, yaitu klon IRR 428 asal isolat Sungei Putih (12,96\%), IRR 429 asal isolat Sungei Putih $(12,96 \%)$, IRR 450 asal isolat Sembawa $(12,96 \%)$ dan IRR 451 asal isolat Sembawa $(14,81 \%)$ serta asal isolat Getas $(14,81 \%)$.

Pengamatan 21 hsi juga menunjukkan bahwa klon pembanding $\mathrm{PB}$ 260 dengan asal isolat Sembawa dan Getas $(12,96 \%)$ memiliki tingkat ketahanan tertinggi. Dari kelompok klon IRR seri 400 terdapat satu klon yang nilai intensitas serangan nya sama dengan klon PB 260, yaitu klon IRR 451 asal isolat Sembawa dan Getas (12,96\%). 
Tabel 4. Pengaruh interaksi klon dengan isolat (K x I) terhadap rataan intensitas serangan Colletotrichum (\%) di kebun entres

Table 4. Effect of interaction clones with isolates $(K \times I)$ toward mean intensity of Colletotrichum attactking (\%) in scion garden

\begin{tabular}{|c|c|c|c|c|c|c|c|c|c|}
\hline \multirow{4}{*}{$\begin{array}{l}\text { Klon } \\
\text { clone } \\
(\mathrm{K})\end{array}$} & \multicolumn{9}{|c|}{$\begin{array}{c}\text { Intensitas serangan } \\
\text { Attack intensity } \\
(\%)\end{array}$} \\
\hline & \multicolumn{3}{|c|}{$7 \mathrm{hsi}$} & \multirow{2}{*}{\multicolumn{3}{|c|}{$\begin{array}{c}14 \mathrm{hsi} \\
\text { Isolat } \\
\text { Isolate } \\
\text { (I) } \\
\end{array}$}} & \multicolumn{3}{|c|}{$21 \mathrm{hsi}$} \\
\hline & & & & & & & & & \\
\hline & SP & SB & GT & SP & SB & GT & SP & SB & GT \\
\hline IRR 425 & 16,7 & 16,7 & 16,7 & 16,7 & 22,2 & 16,7 & 22,2 & 24,1 & 18,5 \\
\hline IRR 428 & 11,1 & 12,9 & 12,9 & 12,9 & 16,7 & 16,7 & 16,7 & 16,7 & 16,7 \\
\hline IRR 429 & 12,9 & 14,8 & 16,7 & 12,9 & 16,7 & 16,7 & 14,8 & 16,7 & 16,7 \\
\hline IRR 431 & 35,2 & 24,1 & 53,7 & 35,2 & 24,1 & 53,7 & 44,4 & 24,1 & 62,9 \\
\hline IRR 434 & 16,7 & 14,8 & 25,9 & 16,7 & 24,1 & 22,2 & 16,7 & 24,1 & 22,2 \\
\hline IRR 437 & 14,8 & 14,8 & 11,1 & 16,7 & 16,7 & 24,1 & 16,7 & 16,7 & 24,1 \\
\hline IRR 440 & 16,7 & 12,9 & 16,7 & 16,7 & 16,7 & 16,7 & 16,7 & 16,7 & 16,7 \\
\hline IRR 443 & 31,5 & 37,0 & 48,2 & 66,7 & 37,0 & 48,2 & 66,7 & 37,0 & 48,2 \\
\hline IRR 444 & 9,3 & 27,8 & 14,8 & 31,5 & 33,3 & 20,4 & 31,5 & 33,3 & 20,4 \\
\hline IRR 445 & 16,7 & 25,9 & 16,7 & 25,9 & 35,2 & 16,7 & 25,9 & 35,2 & 16,7 \\
\hline IRR 446 & 14,8 & 11,1 & 16,7 & 16,7 & 16,7 & 16,7 & 16,7 & 16,7 & 16,7 \\
\hline IRR 447 & 29,6 & 38,9 & 16,7 & 29,6 & 70,4 & 27,8 & 29,6 & 79,6 & 27,8 \\
\hline IRR 448 & 12,9 & 22,2 & 25,9 & 16,7 & 29,6 & 35,2 & 16,7 & 29,6 & 35,2 \\
\hline IRR 449 & 16,7 & 16,7 & 16,7 & 16,7 & 18,5 & 18,5 & 16,7 & 18,5 & 16,7 \\
\hline IRR 450 & 14,8 & 12,9 & 16,7 & 16,7 & 12,9 & 16,7 & 16,7 & 16,7 & 16,7 \\
\hline IRR 451 & 11,1 & 9,3 & 3,70 & 16,7 & 14,8 & 14,8 & 16,7 & 14,8 & 14,8 \\
\hline IRR 452 & 16,7 & 16,7 & 16,67 & 16,7 & 18,5 & 18,5 & 16,7 & 18,5 & 18,5 \\
\hline IRR 453 & 11,1 & 12,9 & 14,81 & 24,1 & 20,4 & 18,5 & 25,9 & 20,4 & 18,5 \\
\hline IRR 454 & 11,1 & 12,9 & 38,89 & 16,7 & 20,4 & 38,9 & 16,7 & 20,4 & 38,9 \\
\hline IRR 455 & 16,7 & 29,6 & 16,67 & 35,2 & 44,4 & 27,8 & 35,2 & 44,4 & 27,8 \\
\hline IRR 456 & 16,7 & 12,9 & 35,19 & 20,4 & 18,5 & 40,5 & 20,4 & 46,3 & 53,7 \\
\hline IRR 457 & 14,8 & 14,8 & 44,44 & 22,2 & 20,4 & 64,8 & 22,2 & 20,4 & 64,8 \\
\hline PB 260 & 14,8 & 3,7 & 11,11 & 20,4 & 12,9 & 14,8 & 20,4 & 12,9 & 12,9 \\
\hline
\end{tabular}

Keterangan: SP: Sungei Putih; SB: Sembawa; GT: Getas

Note: SP: Sungei Putih; SB: Sembawa; GT: Getas

Tidak adanya interaksi antara jenis klon dan jenis isolat diduga karena jenis Colletotrichum yang digunakan sama, yaitu Colletotrichum gloesporioides. Hal ini terbukti dari pengamatan mikroskopik yang dilakukan. Terlihat bahwa dari ketiga jenis isolat tersebut memiliki konidium hialin berbentuk silinder dengan ujung-ujung tumpul, bentuk agak jorong dengan ujung membulat dan pangkal sempit terpancung, tidak bersekat, dan berinti satu (Semangun, 1991)(Gambar 2).

\section{Periode Laten}

Hasil pengamatan terhadap waktu munculnya gejala serangan penyakit (periode laten) adalah tiga hari dari setelah inokulasi. Hal ini menunjukkan bahwa pada 3 hsi telah terjadi penetrasi jamur Colletotrichum ke dalam jaringan daun, dimana pembentukan apresorium berlangsung lebih kurang 12 jam setelah kontak antara konidia dan daun tanaman inang. Apresorium akan membentuk kapak infeksi yang terus menerus menekan kutikula hingga kutikula pecah, kemudian hifa primer mengeluarkan enzim perusak lamela tengah dinding sel sehingga sel-sel daun terpisah-pisah serta dinding sel hancur. Jaringan yang dirusak tersebut khususnya kloroplas sehingga daun yang terinfeksi akan menimbulkan bercak berwarna kuning (Pawirosoemardjo, 1979 dalam Fairuzah et al., 2009). 

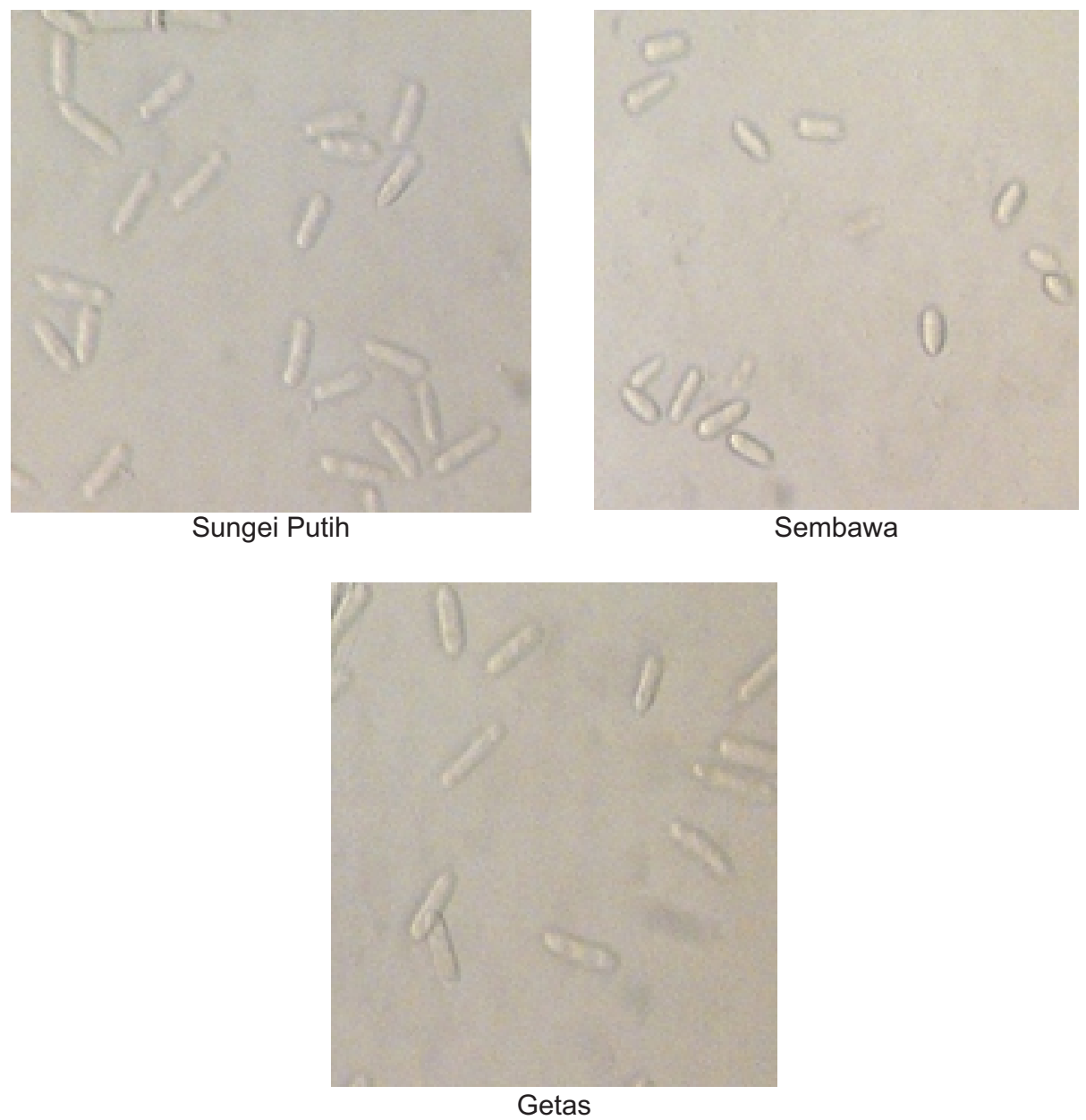

Gambar 2. Hasil pengamatan mikroskopik konidia jamur Colletotrichum gloesporioides pada perbesaran 40X.

Figure 2. Microscopic observation of conidial Colletotrichum gloesporioides fungus at 4OX.

\section{Heretabilitas}

Komponen ragam genotipe $\left(\delta^{2} g\right)$, ragam lingkungan $\left(\delta^{2} e\right)$, ragam fenotipe $\left(\delta^{2} p\right)$ diketahui untuk mendapatkan nilai heretabilitas $\left(\mathrm{h}^{2}\right)$. Nilai heretabilitas pada 7 hsi, 14 hsi dan 21 hsi masing-masing adalah 0,$68 ; 0,71 ; 0,67$. Untuk lebih jelasnya nilai masing-masing komponen ragam yang diamati dapat dilihat pada Tabel 5.

Tabel 5. Analisis komponen ragam dan heretabilitas klon IRR seri 400 terhadap penyakit gugur daun Colletotrichum

Table 5. Analysis of variance components and heretability of IRR 400 clone series to Colletotrichum leaffall disease

\begin{tabular}{lcccc}
\hline \multirow{2}{*}{$\begin{array}{l}\text { Komponen ragam } \\
\text { Variance components }\end{array}$} & \multirow{2}{*}{ Simbol } & \multicolumn{2}{c}{ Nilai analisis komponen ragam dan heretabilitas } \\
\cline { 3 - 5 } & Symbol & Analysis of variance components and heretability & $21 \mathrm{hsi}$ \\
\cline { 3 - 5 } & & 500,52 & 847,36 & 1020,94 \\
Ragam genotipe & $\delta^{2} \mathrm{~g}$ & 227,19 & 350,01 & 499,40 \\
Ragam lingkungan & $\delta^{2} \mathrm{e}$ & 727,71 & 1197,37 & 1520,34 \\
Ragam fenotipe & $\delta^{2 \mathrm{f}}$ & 0,68 & 0,71 & 0,67 \\
Heritabilitas & $\mathrm{h}^{2}$ & &
\end{tabular}


Hasil dari pengaruh faktor genotipe yang terlihat dari karakter intensitas serangan yang diamati di kebun entres pada 7, 14 dan 21 hsi diperoleh nilai heretabilitas yang tinggi. Nilai heretabilitas adalah proporsi besaran ragam genotipe dengan ragam fenotipe. Karakter yang memiliki nilai heretabilitas tinggi akan mudah diwariskan dan lebih stabil sehingga seleksi dilakukan pada lingkungan yang luas dengan hasil yang efektif. Nilai heretabilitas dikelompokkan atas tiga kelompok, yaitu: tinggi: $h^{2}>0,50$, sedang: $h^{2}: 0,20-0,50$, dan rendah $h^{2}:<0,20$ (Syukur et al., 2012). Tingginya nilai heretabilitas yang diperoleh diduga karena klon yang diuji mampu mengaktifkan gen-gen ketahanan yang ada. Salah satu indikator yang dapat dijadikan parameter pengamatan adalah adanya lapisan epidermis daun yang mampu melindungi tanaman dari infeksi patogen jamur Colletotrichum yang diinokulasikan. Klon yang mampu membentuk lapisan kutikula saat masa-masa rentan daun akan terserang. Disamping itu klon tersebut juga memiliki jumlah stomata yang lebih sedikit.

\section{KESIMPULAN DAN SARAN}

\section{Kesimpulan}

Klon IRR 428, IRR 429, IRR 446, IRR 451 dan IRR 452 memiliki tingkat ketahanan yang tinggi terhadap intensitas serangan Colletotrichum. Tidak adanya interaksi antara klon dengan isolat karena jenis isolat adalah Colletotrichum gloesporioides. Tingkat ketahan terhadap penyakit tersebut dipengaruhi klon yang dicerminkan dengan nilai heretabilitas $>0,5$.

\section{Saran}

Uji ketahanan klon IRR seri 400 dapat lebih dipertajam lagi pengamatan secara biologi molekuler.

\section{DAFTAR PUSTAKA}

Aidi-Daslin, S. Woelan, M. Lasminingsih, dan H. Hadi. 2009. Kemajuan Pemuliaan dan Seleksi Tanaman Karet di Indonesia. Prosiding Lokakarya Nasional Pemuliaan Tanaman Karet. Batam, 4-6 Agustus 2009.Pusat Penelitian Karet.: 50-83.
Aziz, A. SAK. 1998. Introducing Research Result Into Practice the Experience with Natural Rubber. In Aziz, A. SAK and Schiweltzer, D.T. (eds) Research Management, RRIM Kuala Lumpur.

Balai Penelitian Sungei Putih. 2011. Evaluasi Rekomendasi Sistem Ekspliotasi Tanaman Karet di KebunKebun PTP Nusantara VIII Jawa Barat. Pusat Penelitian Karet, Medan.

Basuki., S. Pawirosoemardjo, dan A. Situmorang. 1990. Penyakit Gugur Daun Colletrotrichum pada Tanaman Karet Indonesia. Prosiding Lokakarya Nasional Prospek Karet Alam Abad 21. Pontianak, 14-17 Juli. Pusat Penelitian Karet.: 51-64.

Borojevic, S. 1990. Principles and Methods of Plant Breeding. Elsivier Sci. Pub. Co. Inc, New York.

Dalimunthe, C. I., Z. Fairuzah dan I. R. Fauzi. 2014. Persfektif Kerugian Akibat Penyakit Gugur Daun pada Tanaman Karet di Sumatera Utara. Inovasi 11 (3): 3225-232.

Darmono, T. W., A. Darussamin. and S. Pawirosoemardjo. 1996. Variation Among Isolates of Corynespora cassicola Associated with Hevea brasiliensis in Indonesia. Proceeding on the workshop on corynespora leaf fall disease of hevea rubber. Medan, 16-17 Desember. Indonesian Rubber Research Institute.: 79-91.

Fairuzah, Z., Aidi-Daslin dan S.A. Pasaribu 2009. Resistensi Beberapa Klon Karet Terhadap Tiga Isolat Penyakit Gugur Daun Colletotrichum. Prosiding Lokakarya Nasional Pemuliaan Tanaman Karet. Batam, 4-6 Agustus, Pusat Penelitian Karet: 276-287.

Hadi, H. 2003. Analisis Genetik Sifat Ketahanan Tanaman Karet terhadap Penyakit Gugur Daun Corynespora. Disertasi. Institut Pertanian Bogor, Bogor. 
Lopez, A. M. Q. and J. A. Lucas. 2010. Reaction of Dwarf Cashew to Colletotrichum gloesporioides Isolates in Controlled Environment. Sci.Agric.(Piracicaba,Braz.), 67(2): 228235.

Montgomery, Douglas.C. 2001. Design and Analysis of Experiments $-5^{\text {th }}$ Edition. Arizona State University, USA.

Pawirosoemardjo, S. 1984. Beberapa Aspek Hubungan Patogen-Inang dalam Penyakit Gugur Daun Colletotrichum pada Hevea brasiliensis Muell. Arg. Disertasi. Sekolah Pasca Sarjana Institut Pertanian Bogor, Bogor.

Pawirosoemardjo, S. 2004. Manajemen Pengendalian Penyakit Penting dalam Upaya Mengamankan Target Produksi Karet Nasional Tahun 2020. Prosiding Pertemuan Teknis Strategi Pengelolaan Penyakit Tanaman Karet untuk Mempertahankan Potensi Produksi Mendukung Industri Perkaretan Indonesia tahun 2020. Palembang, 6-7 Oktober. Pusat Penelitian Karet.: 2145.

Pawirosoemardjo, S. dan H. Suryaningtyas. 2008. Strategi Pengendalian Penyakit Gugur Daun dan Pencegahan Penyakit Hawar Daun Amerika Selatan pada Tanaman Karet di Indonesia. Prosiding Lokakarya Nasional Agribisnis Karet 2008. Yogyakarta, 2021 Agustus. Pusat Penelitian Karet.: 194-212.

Rahayu, S., Sujatno, dan S. Pawirosoemardjo. 2005. Resistensi Klon Karet Harapan Terhadap Penyakit Gugur Daun Corynespora dan Colletotrichum. Prosiding Lokakarya Nasional Pemuliaan Tanaman Karet. Medan, 22-23 Nopember 2005. Balai Penelitian Sungei Putih. Pusat Penelitian Karet: 275-289.
Saha, T., A. Kumar, A. S. Sreena, A. Joseph, C. K. Jacob, R. Kothandaraman. and M. A. Nazeer. 2000. Genetic Variability of Corynespora cassicola Infecting Hevea brasiliensis Isolated from the Traditional Rubber Growing Areas in India. Indian Journal of Natural Rubber Research 13(1 \& 2): 1-10.

Sa'diyah, N. dan T. N. Aeny. 2012. Keragaman dan Heretabilitas Ketahanan Tebu Populasi F1 terhadap Penyakit Bercak Kuning di PT Gunung Madu Plantations Lampung. Jurnal HPT Tropika 12 (1): 71-77.

Semangun, H. 1991. Penyakit-Penyakit Tanaman Perkebunan di Indonesia. Fakultas Pertanian. Gadjah Mada University Press, Yogyakarta.

Silva W. P. K, B. J. Deverall. and B. R. Lyon 1998. Molecular, Physiological and Phatological Characterization of Corynespora Leaf Spot Fungi from Rubber Plantations in Sri Lanka. Plant Phatology 47 (3): 267-277.

Soepadmo, B. 1975. Colletotrichum gloeosporioides Causing Leaf Fall of Rubber Research Institute of State Crops, Bogor. Paper No.9.

Soepena, H. 1994. Karakteristik Isolat C. gloeosporioides Penyebab Gugur Daun. Buletin Perkaretan 12 (3): 30-38.

Soepena, H. 1995. Colletotrichum acutatum dan Colletotrichum gloeosporioides Sebagai Penyebab Gugur Daun pada Tanaman Karet, Warta Pusat Penelitian Karet 14 (1): 10-14.

Syukur, M., S. Sujiprihati. dan R. Yunianti. 2012. Teknik Pemuliaan Tanaman. Penebar Swadaya, Jakarta. 
Wiratama, I. D. M. P., I. P. Sudiarta, I. M. Sukewijaya, K. Sumiartha dan M. S. Utama. 2013. Kajian Ketahanan Beberapa Galur dan Varietas Cabai terhadap Serangan Antraknosa di Desa Abang Songan Kecamatan Kintamani Kabupaten Bangli. E-Jurnal Agroekoteknologi tropika 2 (2): 71-81.

Woelan, S., Sayurandi. dan S. A. Pasaribu. 2009. Ketahanan Genetik Klon IRR Seri 400 Terhadap Penyakit Gugur Daun Corynespora. Jurnal Penelitian Karet 27(2): 14-25.
Yunasfi. 2002. Faktor-Faktor yang Mempengaruhi Perkembangan Penyakit dan Penyakit yang Disebabkan oleh Jamur. USU digital library.: 1-13. 